\title{
Upper Mantle Composition: Tools for Smarter Diamond Exploration
}

\author{
William L. Griffin \\ GEMOC Key Centre, Dept. Earth \& Planetary Sciences, Macquarie University, NSW 2109, Australia \\ CSIRO Exploration and Mining, North Ryde, NSW 2113, Australia \\ Suzanne Y. O'Reilly \\ GEMOC Key Centre, Dept. Earth \& Planetary Sciences, Macquarie University, NSW 2109, Australia
}

\begin{abstract}
The traditional use of major-element data on diamond indicator minerals such as garnet and chromite is based on empirical correlations that have proven unreliable in some exploration situations. The use of trace-element data on these minerals, combined with mantle-mapping techniques, provides clear explanations of both the successes and the failures of the traditional approaches. These techniques make it possible to determine, at an early stage of exploration, both the overall prospectivity of a region and the most appropriate application of indicator mineral chemistry.
\end{abstract}

Keywords. Diamond exploration, mantle petrology, trace elements, lithosphere mapping

\section{Introduction}

The formation of known economic deposits of gem diamonds has involved sampling of the subcontinental lithospheric mantle (SCLM) by ascending kimberlitic or lamproitic magmas, and much of our knowledge of cratonic SCLM has been a byproduct of diamond exploration and production. The factors that control the distribution of diamond in the SCLM are still incompletely known, although numerous empirical studies have provided constraints. Early studies of diamond inclusions identified an important suite of harzburgitic minerals, especially low-Ca, high-Cr ("G10") pyrope garnets and high-Cr chromites. The use of these as "indicator minerals" has led to some significant exploration successes (especially in S. Africa and Siberia) but has proven misleading in several other regions, leading to significant waste of exploration resources.
However, developments in the use of mantlederived xenocryst minerals to map vertical and lateral variations in SCLM composition (Griffin and Ryan 1995; O'Reilly and Griffin 1996) provide tools that can explain both the successes and the failures, and shed light on diamond formation processes that can be used to improve exploration models.

\section{Mapping SCLM Composition}

The application of single-grain thermometers based on $\mathrm{Ni}$ in garnet and clinopyroxene, and $\mathrm{Zn}$ in chromite (Ryan et al. 1996) allows the depth of origin of each grain to be estimated, by referral of $T$ to a known or assumed geotherm. Such geotherms can also be derived directly from data on garnet and chromite compositions. This approach allows the mapping of mineral chemistry on to depth sections, which contain information on mantle composition, structure and processes (Fig. 1).

\section{Examples}

As an example, SCLM sections from kimberlites in S. Africa and Siberia (Fig. 1) show that harzburgites (olivine-orthopyroxene rocks), identified as important diamond-bearing rock types in these areas, occur mainly at depths that are in the diamond stability field.

However, in the Lac de Gras area of the Slave Province (northern Canada), "G10" garnets and high- $\mathrm{Cr}$ chromites have proven counter-indicative for diamond prospectivity; pipes with the highest proportions of these indicators have low diamond content. One reason for this is apparent in Figure 1. The Lac de Gras SCLM consists of two layers, separated by a sharp discontinuity at $145 \pm 5 \mathrm{~km}$. 

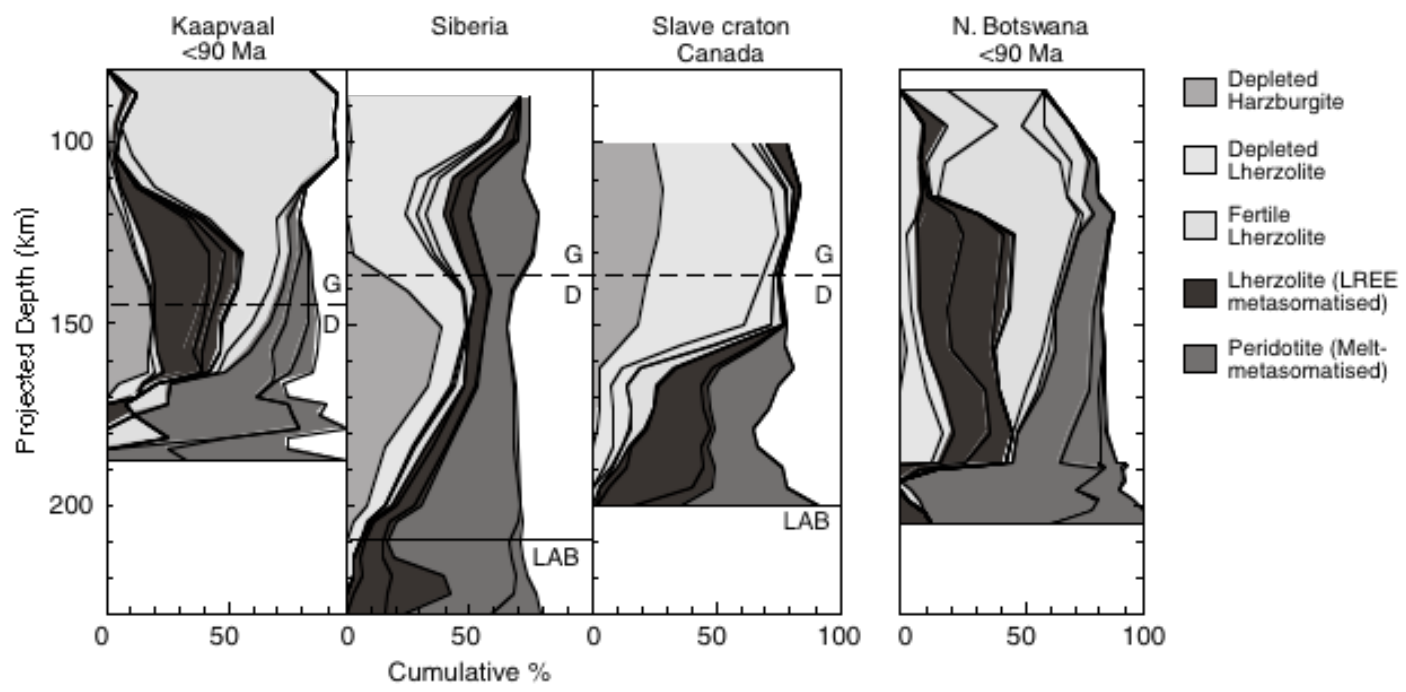

Figure 1: SCLM sections for three representative Archean areas, and the Proterozoic terrain of Northern Botswana. Relative proportions of different rock types have been mapped using major- and trace-element data on concentrate garnets, projected to an empirical geotherm derived for each area. G/D, graphite-diamond transition; LAB, lithosphere-asthenosphere boundary (the base of the depleted lithosphere).

The upper layer is ultradepleted, consisting largely of harzburgite residual after extraction of most basaltic components. The deeper layer (145$190 \mathrm{~km}$ ) is more fertile (richer in $\mathrm{Ca}, \mathrm{Fe}$ and $\mathrm{Al}$ ) and contains little harzburgite; it is interpreted as a subcreted plume head (Griffin et al. 1999, 2004a). Nearly all "G10" garnets and high-Cr chromites come from the upper layer, but only the lowest part of this layer is in the diamond stability field. An analysis of the depth of sampling of Lac de Gras kimberlites shows that those which sampled mainly the upper layer have few diamonds; those that sampled mainly the lower layer are the most diamondiferous.

Studies of inclusions in diamonds from the Lac de Gras area (Davies et al., 1999, 2004) show that the lower layer has a high proportion of diamonds of the superdeep (lower mantle) paragenesis, but about $50 \%$ of the diamonds are derived from eclogites, and particularly kyanite eclogites with high-Ca garnets (which thus are a more important indicator mineral). A map of the distribution of eclogites (Fig. 2), constructed from $\mathrm{T}$ estimates on xenoliths (Pearson et al. 1999; Aulbach et al. 2004) shows that eclogites are concentrated both near the $145-\mathrm{km}$ discontinuity, and at $180-200 \mathrm{~km}$; the varieties with $\mathrm{Ca}$-rich garnets are preferentially concentrated at the base of the SCLM.

The diamondiferous kimberlites of Botswana (Orapa and Jwaneng fields) contain very few "G10" garnets, but abundant diamonds. An SCLM section
(Fig. 1) shows essentially no harzburgites, although Re-Os data show that this SCLM is originally Archean. The abundance of depleted/ metasomatised and fertile lherzolites suggests that the section was refertilised by the introduction of melts during Proterozoic extension and orogeny. In this process, pre-existing harzburgites were converted to lherzolites and their diamonds apparently have been largely destroyed. Diamond

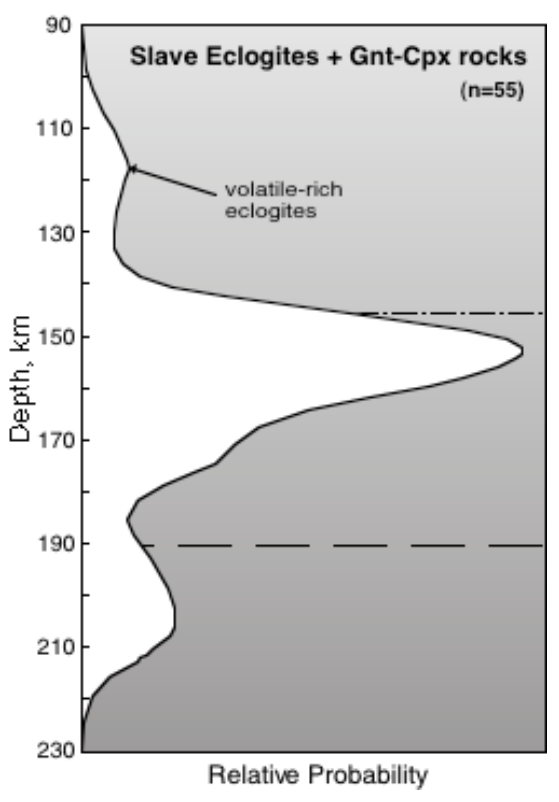

Figure 2: Depth distribution of eclogites in the Lac de Gras area, central Slave Craton. 


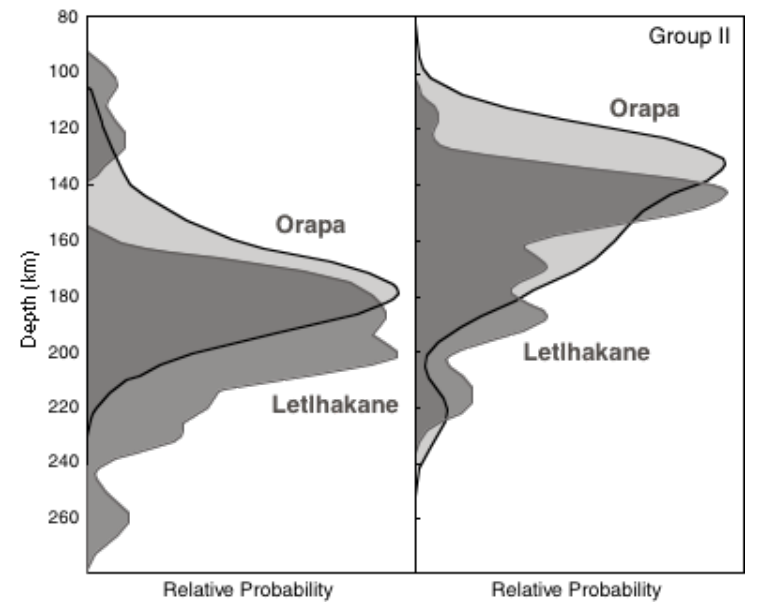

Figure 3: Depth distribution of eclogites beneath the Orapa and Letlhakane kimberlites, N. Botswana. Group I eclogites are diamondiferous; Group II rarely are.

inclusion studies show that most of the diamonds in these pipes are derived from eclogitic rocks. The diamondiferous Group I eclogites are strongly concentrated at the base of the SCLM (Ca $180 \mathrm{~km}$; Fig. 3), and are accompanied by strong melt-related metasomatism (Fig. 1); the non-diamondiferous Group II eclogites are concentrated higher in the SCLM, mostly out of the diamond stability field, which begins at about $150 \mathrm{~km}$ depth in this section. This pattern, and eclogite chemistry, suggest that some asthenospheric melts ponded at the discontinuity represented by the base of the SCLM (Group 1) while some penetrated higher into the SCLM (Group II).

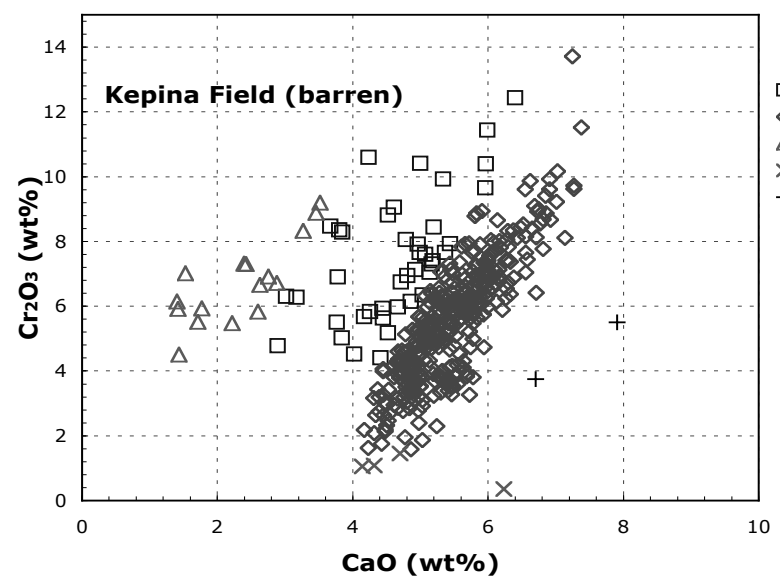

Figure 4: Ca-Cr relationships in garnets from barren kimberlites of the Kepina field, and diamondiferous kimberlites of the nearby Zolotitsa field, Arkhangelsk Province, Western Russia.
In the Arkhangelsk area of western Russia, "G10" garnets are abundant in both diamondiferous and barren kimberlites (Fig. 4). SCLM sections show that the SCLM beneath the barren pipes has been heavily metasomatised and has a significantly higher geotherm than that beneath the fertile pipes; much of this SCLM has been oxidised and heated by the introduction of magmas (represented by abundant megacryst phases crystallised at high pressure), leading to the destruction of diamonds.

The Proterozoic Brockman kimberlite in the Pilbara Craton of Western Australia contains very high proportions of $\mathrm{G} 10$ garnets and high- $\mathrm{Cr}$ chromites (Fig. 5), but few diamonds. The SCLM section (Fig. 6) is dominated by extremely depleted harzburgite, much of it within the diamond stability field. However, the trace-element signatures of the garnets show very little evidence of metasomatism. Diamond formation involves the introduction of carbon, which must be fluid-borne, and therefore related to metasomatism. We suggest that the Pilbara SCLM simply never experienced the metasomatism required to introduce carbon; this type of extreme depletion in mantle rock types thus is a negative indicator of diamond potential. While some metasomatic styles appear to destroy diamonds, it is still unclear which of the different metasomatic signatures that can be recognised in these SCLM sections was responsible for diamond formation. Answers may come from ongoing traceelement studies of the diamonds themselves (Griffin et al., 2004b).

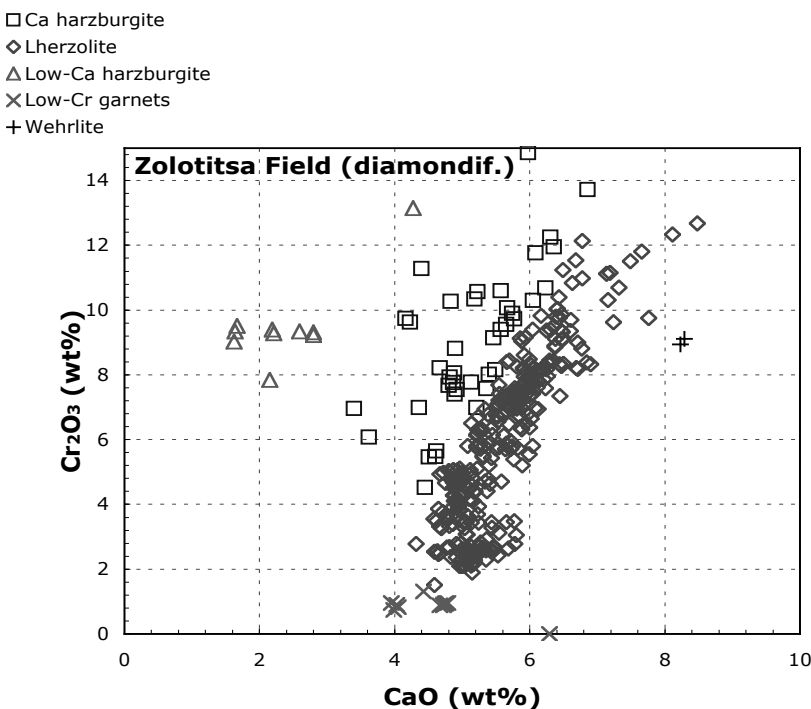




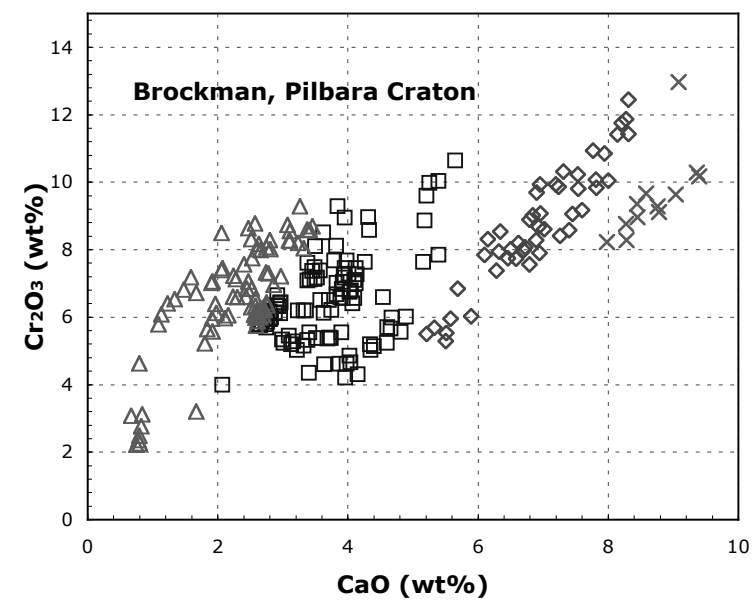

Figure 5: $\mathrm{Ca}-\mathrm{Cr}$ relationships of garnets from the Brockman kimberlite, Pilbara Craton, W. Australia.

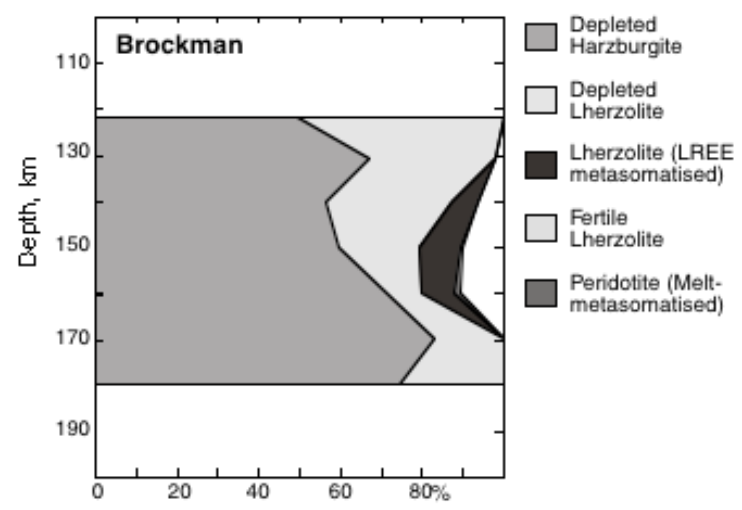

Figure 6: SCLM section from the Brockman kimberlite, Pilbara Craton, Western Australia.

\section{Exploration Applications}

SCLM composition can be analysed at early stages of exploration, using garnets and chromites from drainage/loam/till samples to evaluate the diamond potential of specific regions. Such an analysis should be part of the area selection process. It can be used to identify more favourable and less favourable areas, at an early stage of exploration. It can also be used to prioritise individual indicator trails - that is, "Do I really want to find this pipe?" Both approaches can lead to large savings in exploration resources.

\section{Acknowledgements}

We are grateful to many colleagues, including those in diamond exploration, for input and stimulating discussions over 20 years. Financial support has been provided by industry partners, ARC, CSIRO and Macquarie University.

\section{References}

Aulbach S, Griffin WL, Pearson NJ, O'Reilly SY, Kivi K, Doyle BJ (2004) Mantle formation and evolution, Slave Craton: constraints from HSE abundances and Re-Os systematics of sulfide inclusions in mantle xenocrysts. Chemical Geology 208: 61-88

Davies RM, Griffin WL, Pearson NJ, Andrew A, Doyle BJ, O'Reilly SY (1999) Diamonds from the Deep: Pipe DO27, Slave Craton, Canada. Proc. 7th Int. Kimberlite Conf., Red Roof Design, Cape Town, pp 148-155

Davies RM, Griffin WL, O'Reilly SY, Doyle BJ (2004) Mineral inclusions and geochemical characteristics of microdiamonds from the DO27, A154, A21, A418, DO18, DO27 and Ranch Lake kimberlites, Lac de Gras, Slave Craton, Canada. Lithos 77: 39-55

Griffin WL, Ryan CG (1995) Trace elements in indicator minerals: Area selection and target evaluation in diamond exploration. Jour. Geochem. Explor. 53: 311337

Griffin WL, Doyle BJ, Ryan CG, Pearson NJ, O'Reilly SY, Davies RM, Kivi K, van Achterbergh E, Natapov L M (1999) Layered Mantle Lithosphere in the Lac de Gras Area, Slave Craton: Composition, Structure and Origin. Jour. Petrol. 40: 705-727

Griffin WL, O'Reilly SY, Doyle BJ, Pearson NJ, Coopersmith H, Kivi K, Malkovets V. and Pokhilenko NV (2004a) Lithosphere mapping beneath the North American Plate. Lithos 77, 873-902

Griffin WL, Rege S, Davies RM, Jackson S, O'Reilly SY (2004b) Trace Element Analysis of Diamond by LAM ICPMS: Standardisation, results and directions. Ext. Abst., DeBeers Diamond Conference, Warwick, England

O'Reilly SY, Griffin WL (1996) 4-D lithospheric mapping: a review of the methodology with examples. Tectonophysics 262: 3-18

Pearson NJ, Griffin WL, Doyle BJ, O'Reilly SY, van Achterbergh E, Kivi K (1999) Xenoliths from kimberlite pipes of the Lac de Gras area, Slave Craton, Canada. Proc. 7th Int. Kimberlite Conf., Red Roof Design, Cape Town, pp 644-658

Ryan CG, Griffin WL, Pearson NJ (1996) Garnet Geotherms: a technique for derivation of P-T data from Cr-pyrope garnets. Jour. Geophys. Res. 101: 5611-5625 